\title{
Ekoneni: Yvonne Vera's Challenge to Ocularcentrism in The Stone Virgins
}

\author{
Charlotte BROAD \\ Universidad Nacional Autónoma de México
}

Este ensayo propone explorar las maneras en que algunas escritoras del África del Sur cuestionan el ocularcentrismo, que todavía es un paradigma en el pensamiento occidental, a través de una lectura de la representación del espacio y la ubicación del lector en el primer capítulo de The Stone Virgins (2002), una novela escrita por la zimbabuense Yvonne Vera. "La escritura es un proceso de destilación", dijo una vez su compatriota Tsitsi Dangarembga. Estas palabras son clave en el tratamiento de esta compleja cuestión, en particular, la palabra "proceso". No obstante, lo anterior sólo forma parte de un tema más ambicioso: los modos en que estas escritoras representan la transición del colonialismo a la independencia. En este sentido, la escritura poscolonial demuestra cómo las así llamadas oposiciones binarias conformadas por visibilidad/invisibilidad y habla/ silencio se combinan en procesos que conllevan movimiento e inestabilidad en vez de que dichos elementos permanezcan fijos en un esquema bipolar.

PALABRAS Clave: Yvonne Vera, narrativa del sur de África, poscolonialismo, ocularcentrismo, espacio, conocimiento.

This essay proposes to discuss the ways in which the ocularcentrism, which remains a key paradigm in western thought, has been questioned by Southern African writers, focusing principally on a reading of the representation of space and the location of the reader in the first chapter of The Stone Virgins (2002) by the Zimbabwean Yvonne Vera. "Writing is a distillation process", her countrywoman Tsitsi Dangarembga once said. These words are central to my treatment of this complex issue, which lays particular emphasis on the word process, but this is only one part of a greater theme: the ways in which Southern African women writers represent the transition from colonialism to independence. Postcolonial writing foregrounds how the so-called binaries visibility/invisibility and speech/silence are combined in processes that signify movement and instability, instead of static bipolar separation.

KEY WORDS: Yvonne Vera, Southern African narrative, postcolonialism, ocularcentrism, space, knowledge. 
To Ze nzile Miriam Makeba, Mama Afrika I would love to be remembered as a writer who had no fear for words and who had an intense love for her nation.

Yvonne Vera

Yvonne Vera dared to voice the unspoken and hidden with a scrupulous sensitivity and courage.

Irene Staunton

It is only shallow people who do not judge by appearances. The mystery of the world is the visible, not the invisible.

Oscar Wilde

The progress of Greek ocularcentrism, which interlinks vision, knowledge and reason, is often contested but remains a key paradigm in western thought. Or perhaps I should say in English thought, because, as Ashcroft reminds us: "The verb "I know"” in classical Greek is the perfect form of the verb eido "I see" and both are related to the Latin video "I see" (2001: 126). This equation between sight and knowledge has conferred habits of thought that are difficult to dislodge. My purpose is to discuss the ways in which it has been questioned by Southern African writers, focussing principally on a reading of the representation of space and the location of the reader in the first chapter of The Stone Virgins (2002) by the Zimbabwean Yvonne Vera. "Writing is a distillation process", her countrywoman Tsitsi Dangarembga once said (Veit-Wild, 1995: 28). These words are central to my treatment of this complex issue, which lays particular emphasis on the word process, but this is only one part of a greater theme: the ways in which Southern African women writers represent the transition from colonialism to independence.

Every regime of representation - and representation, or misrepresentation, is a key issue here - is a regime of power formed by the couplet "knowledge/power". ${ }^{1}$ This makes explicit the implications underlying the former equation, in that it is extended to become sight $=$ knowledge=power. Stuart Hall sustains that this knowledge is internal, not external. It is one thing to position a community as the Other of a dominant discourse and quite another to subject it to that "knowledge". The "inner expropriation of cultural identity cripples and deforms" (Hall, 2000: 24). If its silences are not resisted, they produce, as Fanon (1967: 170) puts it, "individuals without an anchor, without horizon, colourless, stateless, rootless - a race of angels". Having discussed cultural identity in terms of one, shared culture, Hall maintains that this second identity highlights difference and rupture. Moreover, it is always in a process of transformation. It is constructed

\footnotetext{
For a discussion of the debates concerning representation and the controversy surrounding it, see, for example, Bi Academic Intervention (1997: 1-12), who summarize the political, semiotic and psychic dynamics of representation and Pimentel (2001), for whom textual representation is central to her study of space in the arts.
} 
through changing histories, memory, fantasy, narrative and myth: "Cultural identities are the points of identification, the unstable points of identification or suture, which are made, within the discourses of history and culture. Not an essence but a positioning. Hence, there is always a politics of identity, a politics of position, which has no absolute guarantee in an unproblematic, transcendental 'law of origin"' (Hall, 2000: 24).

This is noted in W. E. Dubois' concept of double consciousness, which he considered would be the problem of the twentieth century: "One ever feels his twoness - an American, a Negro; two souls, two thoughts, two unreconciled strivings; two warring ideals in one dark body, whose dogged strength alone keeps it from being tom asunder" (Dubois, 1989: 5). How right he was, although in these days it has become a question of "multiple consciousness".

This is exemplified by so many anglophone literary texts of the twentieth century. For instance, Ralph Ellison plays with ocularcentrism in his novel The Invisible Man of 1952. In the Prologue, the narrator explains that he is invisible "simply because people refuse to see me" (1997: 1518). Before discovering the advantages of his invisibility, his life is based on the "fallacious assumption" that he is visible, but in his new knowledge he refuses to pay his electricity bills to "Monopolated Light \& Power". He loves light, however: his new "hole" on the border of Harlem is a "brighter spot" than Broadway or the Empire State Building, which are "among the darkest of our whole civilization [... ] our whole culture" (Ellison, 1997: 1519-1520). This playful interrelation between light and knowledge might tempt us ask ourselves: who possesses the knowledge? Ellison's narrator tells us: "Perhaps you'll think it strange that an invisible man should need light [... ] Light confirms my reality, gives birth to my form. [... ] Without light I am not only invisible, but formless as well; and to be unaware of one's form is to live a death. I myself, after existing some twenty years, did not become alive until I discovered my invisibility" (1997: 1520).

The recognition of his invisibility gives form and life to the author and to his novel. In an act of sabotage, or resistance, he fills his "hole" with light bulbs and has a radiophonograph, so that he can listen to Louis Armstrong, who "made poetry out of being invisible", singing "What Did I Do to Be so Black and Blue".

In this context, Fray Guillermo Baskerville's statement in The Name of the Rose reveals a humorous attempt to close the sign system, which in this case is religious and eurocentric: "[... ] The good of a book lies in its being read. A book is made up of signs that speak of other signs, which in their turn speak of things. Without an eye to read them, a book contains signs that produce no concepts; therefore it is dumb..." (Eco, 1986: 441). ${ }^{2}$

This great imaginary space of the Library elicits different responses, however. Adso de Melk, his young German assistant, a Benedictine novice, realizes when he is in the

\footnotetext{
2 The Spanish translation comes from Dal Píaz' article: "el bien de un libro consiste en ser leído. Un libro está hecho de signos que hablan de otros signos que, a su vez, hablan de las cosas. Sin unos ojos que lo lean, un libro contiene signos que no producen conceptos. Y por lo tanto, es mudo..." (1999: 71).
} 
Library, which "conceals innumerable imaginary spaces created by the books" (Dal Píaz, 1999: 74), that

[... ] not infrequently books speak of books: it is as if they spoke among themselves. In the light of this reflection, the library seemed all the more disturbing to me. It was then the place of a long, centuries-old murmuring, an imperceptible dialogue between one parchment and another, a living thing, a receptacle of powers not to be ruled by a human mind, a treasure of secrets emanated by many minds, surviving the death of those who had produced them or had been their conveyors (Eco: 231). ${ }^{3}$

This murmuring, a talking "in between" and "back" we might call it, underlies many literary works from Southern Africa, situating them in a third space, among different cultural codes. Homi K. Bhabha locates his endorsement of hybridity under a double negative: "neither the one, nor the other". He proposes that a new art might emerge from the working through of these contradictions, provided that it

[... ] demands an encounter with "newness" that is not part of the continuum of past and present. It creates a sense of the new as an insurgent act of cultural translation.

Such art does not merely recall the past as social cause or aesthetic precedent; it renews the past, reflguring it as a contingent "in-between" space, that innovates and interrupts the performance of the present. The "past-present" becomes part of the necessity, not the nostalgia, of living (Bhabha, 1994: 7).

Just as Southern African writers and their characters are constantly caught up in an act of linguistic and cultural translation, so they are translated by others. They have demonstrated that there are many ways of negotiating the colonial tongue and its ideology. Writing back, which includes multiple dialogic strategies, is the best known of these.

Postcolonial writing foregrounds how the binaries visibility/invisibility and speech/ silence, so prominent in western thought, are combined in processes that signify movement, flow, instead of static bipolar separation. In Ashcroft's opinion, these dichotomies have such a hold on those who have been educated under western systems that other ways of knowing, such as "through other senses or other intuitive or imaginary forms of cognition", have been suppressed, "despite post-colonial peoples" "reassertion of the contrary ways of representing place" (Ashcroft, 2001: 127). This limitation of the experience of space makes one realize that one of the underlying concerns is the difference between the ways in which space, always imaginary, is normally represented and the

\footnotetext{
3 Once again the translation is from Dal Píaz's article: "a menudo los libros hablan de libros, o sea que es casi como si hablasen entre sí. A la luz de esa reflexión, la biblioteca me pareció aún más inquietante [... ] era el ámbito de un largo y secular murmullo, de un diálogo imperceptible entre pergaminos, una cosa viva, un receptáculo de poderes que una mente humana era incapaz de dominar, un tesoro de secretos emanados de innumerables mentes, que habían producido, o de quienes los habían transmitiendo..." (1999: 74). I would like to thank Giuliana dal Píaz for these quotations from her fascinating article "Del castillo de Italo Calvino a la biblioteca de Umberto Eco".
} 
ways in which it is experienced: "Sophiatown! How difficult it is to analyse and make comprehensible the magic of the word. As soon as it is written down in black and white, all the life and colour runs out of it", Bishop Trevor Huddleston once wrote - from his eurocentric background - of that "wonderfully mixed" township, in which the people had actually owned their homes. It "became a living symbol of defiance whose art of survival was endlessly celebrated in the theatre, music and literature of the community", a "black spot" or stain on the white face of Johannesburg that "had to be" demolished, "from the authorities" perspective, as it was (Nkosi, 1990: xvii-xviii).

The anticipation and eventual arrival of the period of transition post-1994 has not only inspired South African writers to propose other ways forward but has also reminded them of those who predicted this in the past. As early as 1984, Njabulo Nbedele advanced his theory of the "rediscovery of the ordinary" in his attempt to promote a "literature of affirmation" rather than the tired "protest literature". He demonstrated his aesthetics in his Fools and Other Stories. Both writers and critics alike seek an imagining of the unimaginable. The "literature which South Africa's post-apartheid condition both needs and can deliver", Graham Pechey (1988: 73) suggests, "is the many-voiced discourse of an ekstasis which frees us from the future of hopes and fears and admits us to the sphere of 'unexpectedness', of 'absolute innovation, miracle"' (Bakhtin, 1986: 167). Representation has been called into question. It may refigure, to use Bhabha's term, that common ground so typical of Southern African writing, it may be revised, resisted (anti-nationalism) and/or lay emphasis on the interlinking of the senses. I am not suggesting that these writers have discovered anything new; what I am suggesting is that the artist's insistence on other ways of knowing offers such a critique of "the centre's traditions of writing that he can invent in fiction a 'South Africa' which challenges the settled truths of centre and margin alike", as Pechey says of J. M. Coetzee (1998: 67). Ndebele, in turn, posits such a popular and local knowledge that he does not "seem to need an addressee in the old metropolis". Thus, these two writers communicate with the world "by speaking from their own chronotope to the chronotopes of their potential readers abroad". ${ }^{4}$ At the end of Ndebele's story "Uncle" of 1984, which is the most explicit rendering of his concept of the rediscovery of the extraordinary in the ordinary, there is a township gathering where jazz is played. The improvised interlinking of "the gramophone, the trumpet, the concertina, the guitar, the mouth organ, the hooting cars" recalls Uncle's earlier instruction to his nephew: "You see, when you are improvising you are free. You've got to struggle hard for that freedom" (Ndebele, 1985: 122, 76-77). This new imagining, stemming from the ordinary and moving beyond the description evoked by sight and sound, transcends the word. Generally speaking, it reminds us, of course, of the struggle underlying artistic creation.

\footnotetext{
4 In The Dialogic Imagination, Bakhtin defines the chronotope as "the intrinsic connectedness of temporal and spatial relationships that are artistically expressed in literature" (1981: 84-85). In the chronotope time "thickens, takes on flesh" while "space becomes charged and responsive to the movements of time, plot and history". Cf. G. Pechey (1998: 67).
} 
Bessie Head might well have been the grandmother who told Zhizha, the young protagonist of Vera's Under the Tongue: "a woman endures, becomes only a memory of her yesterdays" (Vera, 1996: 39). ${ }^{5}$ Her mother tells her: "We live with words" (Vera, 1996: 82). Words flow, words comes from the river: Zhizha lost her voice, however, when her father raped her. Her mother teaches her to speak again, as they look at each other in the mirror. Zhizha's recovery of speech, and thus the recovery of agency over her body, is linked to her mother's lessons in how to make the language her own (Samuelson, 2003: 19). Her writing on the steamed mirror brings to mind Vera's words of 1999: "If speaking is still difficult to negotiate, then writing has created a free space for most women..." (Vera, 1999: 3). The emergence of African women writers, so often neglected in international circles, has brought about a re-evaluation of the existing canon and a questioning of its imaginings and imaginary: "Women have not only introduced new paradigms but are changing existing paradigms" (Ravell-Pinto, 1995: 126). For example, Bessie Head, who obtained an exit permit in 1964 to leave South Africa for Botswana, offers a model for the new aesthetics of transition in A Question of Power, her experimental novel of 1974, which combines personal retrospect, spiritual allegory and a recipe for gooseberry jam. It is "the mixing and permutation of forms which in literature gives an occasion and a framework for new imaginings" (Boehmer, 1988: 47).

The late Yvonne Vera's writing seems to have anticipated the route the South African women writers proposed for their transitional writing. The Stone Virgins foregrounds the difficulties the anglophone writer faces in her attempt to re-present the brutalities of the country's history from the War of Liberation to the horrors of the early 1980s. ${ }^{6}$ As the first Zimbabwean woman novelist who had the courage and sensitivity to respond to the post-Independence atrocities, her choice of "a beheading and mutilation, and of the destruction of a [village] store, shows great restraint" (Ranger, 2003: 209). This text criticizes colonialism, oppositional nationalism and patriarchal structures: as in her other works, silence, a sign of resistance politics, "is posed as the standard response to the trauma of colonial and national 'rape"' (Samuelson, 2003: 15).

The narrative treats of two sisters, Thenjiwe and Nonceba, who grew up in the village of Kezi, through the troubled years of the Liberation war. Independence brings a new spirit of freedom and excitement, which is killed by a period of intense brutality and suffering in 1980s when Joshua Nkomo's Peoples' Liberation Army (ZIPRA) is targeted

5 Endure is a word Vera often uses. When Larson asked her about her controversial subject matter - rape, incest, abortion — she responded by saying: "Women have been expected to be the custodians of our society as well as its worst victims [. ] There are beauties, too, and I write about them, our combined capacity as Zimbabwean men and women to endure all we have experienced in colonial times and today" (2001: 84).

6 Jane Bryce explains: "During the liberation war, the Shona and Ndebele peoples were represented by the different armies, ZANLA and ZIPRA, with different leaders". At Independence, Robert Mugabe, the ZANU-PF leader, took power and Joshua Nkomo was sidelined. "There ensued a backlash by the ruling ZANU-PF party against the Ndebele in the south" (2003: 224). 
by the new regime and some of his ex-guerrillas. The dissident Sisabo comes down out of the hills, beheads Thenjiwe and cuts off the lips of her sister. When Cephas Dude, Thenjiwe's former lover, reads about this atrocity, he rescues Nonceba and takes her away from the "open cemetery" of Kezi and back to the city of Bulawayo - the name of this city means "the place of slaughter".

Vera tells her interviewers that she has been influenced by film, particularly by "how images are prepared, constructed and made to move". ${ }^{7}$ Thus, she starts her novels with a visual, mental moment "as though it were a photograph", but this analogy assures us that it goes beyond the visual: "This moment, frozen like that, is so powerful that I can't lose sight of it, visually or emotionally. [... ] Everything ripples around that, the story grows out of that image"; indeed "an entire history is contained in a moment" (Bryce, 2003b: 219). The Stone Virgins is inspired by a photograph "of a woman being decapitated" (Bryce, 2003b: 224). But her question is: "How do I convey that in a way that interests the reader? "She refuses to cast it to one side, because it is "so awkward, ugly, messy, bloody". She wants it to be read, "when it is encountered, as an astounding, beautiful, creative experience". So she decides to choreograph it: "The death becomes like a dance, the way the man kills this woman is almost sexual... " Our question is: how does she achieve this? The first chapter of this novel, in which the narrator's images construct different "realities" of Bulawayo, a city in the southwest of Zimbabwe, gives us many a hint to her future narrative strategy.

Throughout her writing life, Vera generally records the "biographies of unknown women" (Bryce, 2003b: 223), but in The Stone Virgins, somewhat like her first novel Nehanda, the spider's web interweaves histories with History, showing her interest in Zimbabwe's "national history". ${ }^{8}$ These biographies are always against the backdrop of a particular time. The first chapter uses, as Bryce also suggests (2003a: 67), the structuring technique of montage, by representing a sequence of images of the colonial city, which play with perspective and focalization ${ }^{9}$ and focus principally on Selborne Avenue. ${ }^{10}$ Of course, the perception of these images also depends on the reader bringing "extratextual information to bear on what is seen in the frame in order to make [some] sense of it"

\footnotetext{
7 Interestingly, Vera's interviewers have reported personal and e-mail conversations with her before her sad death at such a young age in April 2005.

8 Nehanda is a Ndebele woman "who rose to prominence as a spirit medium during Zimbabwe's anti-colonial struggle and whose heroism continues to inspire many today, as attested to by different testimonies of admiration and respect among blacks throughout the diaspora". For a discussion of this novel from a feminist stance, see Desiree Lewis, "Revisioning Patriarchal Nationalism: Yvonne Vera's Nehanda". 2002. JCAS joint research project on state, nation and ethnic relations. International symposium $\mathrm{N}^{\circ}$ 7, Osaka, Japan (accessed 28/10/10).

9 Mieke Bal defines focalization as "the most subtle means of manipulating information presented to the reader... "It is "the relationship between the "vision', the agent that sees, and that which is seen" (1996: 118). Though this can be thought of in quite different terms, this definition demonstrates the ocularcentrism of western thought.

${ }^{10}$ Many of the street names have changed since then. Selborne Avenue is now called Leopold Takawira Avenue.
} 
(Mirzoeff, 2000: 7), which can never complete the picture. As we discover, fragmentary representation here questions the horizon of expectations as well as the horizon of other knowledge available by means of other texts (Ashcroft, 2001: 72-73).

Significantly, the chapter is divided into several sections with a blank space between each section, anticipating the structure of the novel. The narrator opens with a shot down Selborne Avenue ("proud of its magnificence") lined by different flowering trees, depending on the season of the year. It runs "from Fort Street (at Charter House), across to Jameson Road (of the Jameson Raid), through to Main Street, to Grey Street, to Abercorn Street, to Fife Street, to Rhodes Street, to Borrow Street, out into the lush Centenary Gardens with their fusion of dahlias, petunias, asters, red salvia and mauve petrea bushes onward to the National Museum, on the left side". ${ }^{11}$

The subsequent mention of a man taking photos whenever there is a wedding emphasizes this appeal to the visual, which clearly distinguishes colonial from national structures, nature from colonial architecture: like our narrator, the photographer "shields his lens from glare, from spray, but not from blooms". Does nature act as a decolonising agent? This imaginary urban space, so silent, so white and so empty - the colonial eye is blind to the inhabitants - introduces the outsider into this narrative universe, ironically on the terms of that common ground of preserving the colonial image in colonized countries: "I detest that image! What's more, it's a lie", Caliban tells Prospero at the end of Une Têmpete by Aimé Césaire. ${ }^{12}$ By naming a city, its streets and their peculiar features, the narrator creates a network of meanings, which go far beyond the visible and the visualized. This colonial figure thus embodies a multiplicity of cultural and ideological significations (Pimentel, 2001: 30-33).

"I want you to be a witness, which means taking part in what is happening each moment, as it happens", Vera insists of her reader (Bryce, 2003b: 222-225). In the next section, the narrator addresses her narratee directly, who appears to be an outsider: "You can look down Selborne Avenue for miles and miles with your eyes, encountering everything plus blooms". It takes you to "Ascot Race Course, where the horses bristle and canter past the Matsheumhlope River" and to "these fine suburbs" - the townships are not mentioned- where smaller "secluded" streets are named "after English poets - Kipling, Tennyson, Byron, Keats and Coleridge” (Vera, 2002: 4-5). This listing of street names in a syntagmatic chain creates, as Luz Aurora Pimentel puts it, that contradictory ideal of a description (2001: 19). It is both synthetic (the conviction that one can grasp a range of ideas simultaneously through sight) and analytical (the rational act of knowing). The contract of intelligibility proposed by these first descriptions of the urban space conveys a specific ideological stance, a set of values the reader may or may not agree with (Pimentel, 2001: 10), although we should remember that the reader

11 Towards the end of the novel, we discover that Cephas Dude, one of the main male characters, works "for the archives of the National Museums and Monuments of Zimbabwe" in Bulawayo (Vera, 2002: 163). Vera's last position was that of the Director of the National Gallen of Zimbabwe in Bulawayo.

$12 C f$ "Homage to Aimé Césaire". www. ambafrance-gh. org (accessed 04/04/2010). 
of our times, be s/he postcolonial or not, would resist such a binary schema. The colonial gaze focuses on such things as smart weddings and monumental buildings, which recalls their imperialist heritage. The reference to the gardens, which celebrate some centenary, makes us aware that we are in a temporal void, surrounded by monuments commemorating a distant past, described in such a manner that they have lost any sign of power assigned to them at the beginning. Besides these gardens and the National Museum, the naming of the Matsheumhlope River, which may function to create "a reality effect", is the one sign that contests the initial contract of intelligibility.

The term "imaginary" has many resonances, especially with notions of representation, identity and identification (Bi Academic Intervention, 1997: 2). This urban representation might appeal to the "cultural imaginary", a repertoire of cultural images and meanings which may be called upon to make sense of the world(s) in which we live. But who are "we"? This question reveals how the narrator challenges the image she has presented. The empty city constructed and configured by the colonialists casts an ominous shadow over the narrative: "certain absences are so stressed, [... ] so planned, they call attention to themselves; arrest us with intentionality and purpose, like neighbourhoods that are defined by the population held away from them" (Morrison, 1990: 210). The fusion of street names and historical events elicit very different responses from the readers. These would depend, for example, on whether they have or have not been colonized by the British, on whether they live in Bulawayo today or lived there in the past, and on many other factors.

The next section points to another landmark, a sign(post), which bears other political implications: "Selborne carries you straight out of the city limits and heads all the way to Johannesburg like an umbilical cord, therefore, part of that city is here, its joy and notorious radiance is measured in the sleek gestures of city labourers, black, who voyage back and forth between Bulawayo and Johannesburg and hold that city up like a beacon" (Vera, 2002: 5). Ironically, it is the visits of the migrant workers, who have had to seek a job elsewhere because of the former white seizing of land, that bring this city alive. Not only are they black, but they are outsiders, as much in Johannesburg, where they enjoy their anonymity, as in their home town: "The way they pronounce the name of that city, say it, fold it over the tongue, tells you everything; you can see the scaffolding and smell frangipani at nighttime, in Jo'burg" (Vera, 2002: 6). Seemingly evocative, their pronunciation of that city and of egoli (gold) conceals the claustrophobia below and above ground, at home and in Johannesburg, caused by the oppressive and cruel regimes: they "know how to evade gazes. They can challenge the speculative, the hostile and suspicious enquiries about their presence in the city" (Vera, 2002: 5). These suspect workers, dressed in "double-vent jackets and their bright scarves", put Vera's choreography into play, as they perform on their side of the city and in stereotypical fashion, "some gumboot dance, some knuckle ready sound, some click song” (Vera, 2002: 6).

The atmosphere anticipated by the workers grows much more intense in the next image represented of a "secluded black bar" —note the use of "secluded" again, in quite 
a different context - in the basement of one of the "finest hotels on Selborne Avenue". Here "nothing is permanent", but the blinding smoke, the "music beating against their soles" and the "humming voices". The first shot is of a woman moving sensuously in a short skirt with laddered stockings. A man's "solid" gaze falls on her, "on this skirt", and "these knees" (Vera, 2002: 8). Everything interests him: "the movement of each chair, the betrayals, the voices intertwined, the smoke circling the knees". He "takes a sip" from the woman's perfume and feels her toe touching his knee. Our gaze is directed to the trumpeter, who with his "eyes squeezed blind" plays "his Skokiaan with Louis before his eyes". He "is crossing that line" and his audience long for the day when this man rather than Satchmo can "carry their own desires above ground - somewhere". Below the surface is a turbulence of intermingling sensations, dreams, and loyalties: "The country is landlocked, bursting. The war is in their midst" (Vera, 2002: 8). The people dream about independence: "All they want is to come and go as they please. Satchmo" (Vera, 2002: 9).

The horizon of experiences of this city expands as the focus turns to a street cleaner sweeping "the comer along Main Street, at Douslin House" (Vera, 2002: 9). Built on a grid by the British, Bulawayo "revolves in sharp edges, $[\ldots]$ the edge of a building is a profile, a comer... ekoneni. The word is pronounced through pursed lips and lyrical minds, with arms pulsing, with a memory begging for time. Ekoneni, they say, begging for ease, for understanding" (Vera, 2002: 10). The various descriptions of the ekoneni, notably spoken of in the local tongue, reveal the dark recesses of fear and dread, the real legacy of the British. It is a vista, "and Selborne Avenue is stretching from your forehead all the way to the stars. Your fear floats to the skin, like touch". Has the narratee changed? It is a place to meet: "You cannot meet inside any of the buildings because this city is divided, entry is forbidden to black men and women. Here, you linger, ambivalent, permanent as time. You are in transit. The comer is a camouflage, a place of instancy and style; a place of protest".

It is "also a dangerous place, where knives emerge as suddenly as lightening". It is, finally, a rendezvous for lovers: "the purpose of this encounter is to establish which of the two lovers is the survivor, which the quiet mind - which one is imbued with disasters, which is the channel of forgiveness, which one is the accuser, the architect of guilt" (Vera, 2002: 10-11). The comer, a space imposed by colonial architecture, now becomes the focus of the narration, as it is visualized from many different perspectives, as it further emphasizes the cultural difference of the inhabitants. It demonstrates how "horizonality", a function of both production and reception, can dismantle ocularcentrism in post-colonial discourse (Ashcroft, 2001: 190). Rather than producing polarity and incomprehension, it becomes the grounding for the transformation of both the imposed boundaries, bringing the turbulence in the bar above ground, and the initial contract of intelligibility (Ashcroft, 2001: 189). The metonymic gap created by the introduction of an indigenous word detaches the text from the colonial language system. By objectifying the "conception of the world' facet of both languages", their "internal form" and their "respective systems of values", it produces a dialogue between the two, as Bakhtin puts 
it (Todorov, 1984: 64). Standing for the local culture, its resistance to interpretation and to cultural colonization creates yet another gap between the writer's culture and the colonial culture. These sharp edges are now "the unstable points of identification" signifying the narrator's positioning in the story to be told (Hall, 2000: 24).

In the final scene, the focus is firstly on a woman moving towards the bus station and then on a departing bus, as she jostles amid bodies, tomatoes, "the smell of guava fruit, mingling, with the braking wheels". Once all are on the bus, the narrator turns to her more affluent witness once more: if "you turn from Selborne Avenue into Grey Street and go west, you can drive all the way out, as they could drive out to the suburbs, to the ancient Matopo Hills, those tumbling rocks reaching out to the lands of Gulati, past that to Kezi" (Vera, 2002: 14). ${ }^{13}$ From Bulawayo, all directions take us to other such places, be it Johannesburg or inland to the heart of the independence conflict, the main setting of The Stone Virgins.

In sum, after this brief summary that illustrates Vera's distinction as a writer, we might suggest that the montage in this chapter casts an ominous shadow over the rest of the narrative. As the narrator empties the colonial image of power, the other images she presents as almost familiar and recognizable are stealthily undermined, intensifying the atmosphere and darkening the mood. Moreover, her change in focus from one image to another, one scene to another, one perspective to another, not always giving us that comfort of context, anticipates how she will choreograph a text that spans the period from the 1950s to the 1980s. The isolation caused by fear, by the fragmentation of experience, by the intensification of atmosphere and mood are among the many characteristics that make this narrative so dramatic and moving. The contextualizing spotlight cast on several of the actors does not overtly condemn the murdering dissenter, but begs many questions of the reader. Just as the narrator radically changes the positioning of the subject and the narratee in one chapter, thereby opening the text to other means of acquiring knowledge, so she questions the imposed significance of linguistic, literary and architectural boundaries. Her reconfiguration of the city challenges the western domination of such binary oppositions as visibility and invisibility, sound and silence, even if I have argued, somewhat paradoxically, that Vera's interests lie in visibility and silence. As we see in the first chapter, however, the transformation of the place of the local inhabitants and of our location as readers involves engagement with the boundaries of power. The first chapter of this novel includes, in those metonymic gaps, a questioning of representation in the development of anglophone literature in this conflictive country. Representation is particularly questioned if, as Ashcroft puts it, we tend to think of poetic imagery as primarily visual, because visual perception has become the metonym of consciousness itself $(2001: 127,172)$. 
Works cited

Ashcroft, Bill. 2001. Post-colonial Transformation. New York / London: Routledge.

BAKHTIN, Mikhail. 1986. Speech Genres and Other Late Essays. Ed. Caryl EMERSON and Michael Holquist. Austin: University of Texas Press. . 1984. Problems of Dostoevsky's Poetics. Ed. Caryl EMERSON. Manchester: Manchester University Press. . 1981. The Dialogic Imagination. Ed. Michael HolQUIST. Austin: University of Texas Press.

BAL, Mieke. 1996. Narratology. Singapore: Longman.

Bi ACADEMIC Intervention. 1997. "Introduction". The Bisexual Imaginary. Representation, Identity and Desire. Ed. Bi Academic Intervention. London / Washington: Cassell.

BOEHMER, Elleke. 1998. "Endings and new beginnings: South African fiction in transition”. Writing South Africa. Literature, apartheid' and democracy 1970-1995. Ed. Derek ATTRIDGE and Rosemary JOLLY. Cambridge: Cambridge University Press.

BRYCE, Jane. 2003a. "Imaginary snapshots: cinematic techniques in the writing of Yvonne Vera”. Sign and Taboo: Perspectives on the Poetic Fiction of Yvonne Vera. Ed. Robert MuPONDE and Mandi TARUVInGA. Oxford: James Currey. . 2003b. "Interview with Yvonne Vera". Sign and Taboo: Perspectives on the Poetic Fiction of Yvonne Vera. Ed. Robert MuPONDE and Mandi TARUVINGA. Oxford: James Currey.

DAL PIAZ, Guiliana. 1999. "Del castillo de Italo Calvino a la biblioteca de Umberto Eco: espacios imaginarios en la literatura italiana del siglo XX”. Espacios imaginarios. Coord. María Noel LAPOUJADE. México: UNAM.

Dubois, W. E. B. 1989 (1904). The Souls of Black Folk. Harmondsworth: Penguin Books.

EcO, Umberto. 1986. The Name of the Rose. Trans. William Weaver. San Diego: Harcourt Brace Jovanovich.

ELlison, Ralph. 1997 (1952). "Prologue" to The Invisible Man. The Norton Anthology of African American Literature. Ed. Henry Louis GATES Jr. and Nellie Y. MCKAY. New York: W. W. Norton \& Company.

Espacios imaginarios. 1999. Coord. María Noel LAPOUJADE. México: UNAM.

FANON, Frantz. 1967. The Wretched of the Earth. Harmondsworth: Penguin Books.

HALl, Stuart. 2000. "Cultural Identity and Diaspora”. Diaspora and Visual Culture. Representing Africans and Jews. Ed. Nicholas MirzOEFF. London: Routledge.

LARSOn, Charles. 2001. The Ordeal of the African Writer. London / New York: Zed Books.

MiRzOEFF, Nicholas. 2000. "Introduction. The multiple viewpoint: diasporic visual culture". Diaspora and Visual Culture. Representing Africans and Jews. Ed. Nicholas MIRZOEFF. London: Routledge. 
NDEBELE, Njabulo S. 1994. South African Literature and Culture. Rediscovery of the Ordinary. Intro. Graham Pechey. Manchester: Manchester University Press. . 1985. Fools and other stories. Harlow: Longman Group.

NKosI, Lewis. 1990. "Introduction”. Bloke Modisane. 1990. Blame Me on History. Harmondsworth: Penguin Books.

PECHEY, Graham. 1998. "The post-apartheid sublime: rediscovering the extraordinary". Writing South Africa. Literature, apartheid, and democracy, 1970-1995. Ed. Derek ATTRIDGE and Rosemary Jolly. Cambridge: Cambridge University Press.

PIMENTEL, Luz Aurora. 2001. Espacio en la ficción. La representación del espacio en los textos narrativos. México: Siglo XXI Editores.

RANGER, Terence. 2003. "History has its ceiling. The presence of the past in The Stone Virgins Sign and Taboo: Perspectives on the Poetic Fiction of Yvonne Vera. Ed. Robert MUPONDE and Mandi TARUVINGA. Oxford: James CURREY.

Ravell-Pinto, Thelma M. 1995. "Women's Writing and the Politics of South Africa: The Ambiguous Role of Nadine Gordimer". Moving beyond boundaries. Vol. 2: Black Women's Diasporas. Ed. Carole BoYCE DAVIES. New York: New York University Press.

SAMUELSON, Meg. 2003. "“A River in my Mouth': writing the voice in Under the Tongue"'. Sign and Taboo: Perspectives on the Poetic Fiction of Yvonne Vera. Ed. Robert MUPONDE and Mandi TARUVINGA. Oxford: James CURREY.

The Bisexual Imaginary Representation, Identity and Desire. 1997. Ed. Bi Academic Intervention. London / Washington: Cassell.

Todorov, Tzvetan. 1984. Mikhail Bakhtin. The Dialogical Principle. Trans. Wlad Godzich. Manchester: Manchester University Press.

Toni Morrison. 1990. Ed. Harold Bloom. New York: Chelsea House.

VEIT-WILD, Flora. 1995. "Women Write about the Things That Move Them". A Conversation with Tsitsi Dangarembga. Moving beyond boundaries. Vol. 2: Black Women's Diasporas. Ed. Carole Boyce Davies. New York: New York University Press. VERA, Yvonne. 2002. The Stone Virgins. Harare: Weaver Press. . 1999. "Introduction". Opening Spaces. Ed. Yvonne Vera. Oxford: Heinemann Educational Publishers. . 1996. Under the Tongue. Harare: Baobab Books. 